\title{
Potencjał produkcji biogazu wybranych traw wieloletnich z rodzaju stokłosa
}

\author{
The biogas potential of selected perennial grasses from genus bromus
}

Grzegorz Żurek $^{1 凶}$, Marcin Martyniak ${ }^{2}$

${ }^{1}$ Instytut Hodowli i Aklimatyzacji Roślin - Państwowy Instytut Badawczy, Radzików, 05-870 Błonie,
2 Uniwersytet Warszawski, Wydział Zarządzania, Warszawa
$\square$ e-mail: g.zurek@ihar.edu.pl

W pracy zaprezentowano wyniki oceny plonowania oraz badań laboratoryjnych parametrów związanych z produkcją biogazu dwóch gatunków z rodzaju stokłosa (bezostna oraz obiedkowata) w porównaniu do tetraploidalnej odmiany życicy trwałej. Kiszonki przygotowano z całych roślin w fazie kłoszenia, w warunkach laboratoryjnych w rękawach foliowych. Biogazodochodowość oznaczano metodą eudiometryczną wg akredytowanej procedury badawczej implementowanej normy DIN 38 414-S8:1985. Wraz z analizą wyników przedstawiono możliwość wykorzystania badanych kiszonek jako alternatywnych substratów dla biogazowni rolniczych.

\begin{abstract}
Słowa kluczowe: biogaz, kiszonka z traw, Lolium perenne, Bromus catharticus, Bromus inermis, stokłosa
The paper presents the results of the assessment of yield and laboratory tests of biogas parameters of two species of the genus Bromus, compared to the tetraploid perennial ryegrass. Silage was prepared from whole plants in the heading phase, using the laboratory method in plastic sleeves. Biogas yield was determined by the eudiometric method according to the accredited testing procedure of the implemented DIN 38 414-S8: 1985 standard. Along with the analysis of the results, the possibility of using the examined silage as alternative substrates for agricultural biogas plants was presented.
\end{abstract}

Key words: biogas, grass silage, Lolium perenne, Bromus catharticus, Bromus inermis, rescue grass, brome grass

\begin{abstract}
Wstęp
Aby zapewnić rozwój gospodarczy przyjazny środowisku, Unia Europejska wyznaczyła priorytety, w których zrównoważona polityka klimatyczna i energetyczna państw powinna się opierać $m$. in. na oszczędności energii oraz na rozwoju energii pozyskiwanej ze źródeł odnawialnych. Zgodnie z Dyrektywą 2009/28/WE biomasa „agro" może stanowić największe źródło surowców do produkcji bioenergii rozproszonej, szczególnie na obszarach o niskiej wartości rolniczej (gleby ubogie, wymagające rekultywacji, itp.), równocześnie przyczyniając się do ograniczenia importu biomasy z zagranicy. Nowe formy traw i inne rośliny energetyczne o dużym potencjale plonowania i przydatności do zakiszania mogą być czynnikiem aktywizującym koniunkturę polskiego rolnictwa, co łącznie ma duże znaczenie gospodarcze, ekonomiczne i ekologiczne. Biomasa roślinna, zwłaszcza traw, może stanowić największe potencjalne źródło czystej energii w kraju, Europie i na świecie. Jednym z najistotniejszych źródeł energii odnawialnej jest produkcja biogazu, dostarczająca dodatkowo korzyści
\end{abstract}

środowiskowych i mogąca zwiększyć dochody rolników (Oslaj i in. 2010). Ważnym elementem, warunkującym rozwój biogazowni jest możliwość zapewnienia stałego dopływu surowca, szczególnie pochodzenia roślinnego. Równocześnie biogazownie stanowią źródło energii na obszarach słabiej zurbanizowanych. Inwestycje związane $\mathrm{z}$ pozyskiwaniem biogazu są $\mathrm{w}$ grupie działań przewidzianych do realizacji dla poprawy bezpieczeństwa energetycznego kraju w Strategii na Rzecz Odpowiedzialnego Rozwoju do roku 2020. W wyniku realizacji planu stabilizacji cen żywności, chętnie wykorzystywane energetycznie rośliny takie jak kukurydza, zboża, czy buraki cukrowe w najbliższych latach będą sukcesywnie zastępowane alternatywną biomasą o wysokim plonowaniu i wysokim potencjale biogazowym np. sorgo (Matyka, Księżak 2012).

Możliwe jest również pozyskiwanie biomasy z upraw prowadzonych na nieużytkach lub gruntach o niskiej przydatności rolniczej, przy zastosowaniu wieloletnich gatunków traw o specyficznych predyspozycjach i zdolności do wykształcania biomasy, której parametry 
technologiczne nie będą wymagały zmian w technologii eksploatacji instalacji biogazowych. Istnieje zatem konieczność przebadania różnych, również mniej popularnych, gatunków traw wieloletnich, dla uzyskania informacji o ich potencjalnej przydatności.

Spośród wielu gatunków traw wieloletnich przydatnych do uprawy w Polsce, istnieją takie, które spełniają podstawowe kryteria przydatności do uprawy na terenach o niskiej wartości rolniczej. Sa to gatunki o opisanych w literaturze predyspozycjach do wzrostu i rozwoju również na gruntach o niskiej wartości rolniczej jak np. kostrzewa trzcinowata (Festuca arundinaca Schreb.), mozga trzcinowata (Phalaris arundinacea L.), perz wydłużony (Elymus elongatus (Host) Runemark), stokłosa bezostna (Bromus inermis Leyss.) czy stokłosa obiedkowata (Bromus catharticus Vahl.). O ile pierwsze z wymienionych powyżej gatunków posiadają już udokumentowane charakterystyki jakości biomasy, zarówno w procesie spalania jak i produkcji biogazu (Dickeduisberg i wsp. 2017; Mast i wsp. 2014; Lalak i wsp. 2016; Kulig i wsp. 2015; Martyniak i wsp. 2017; Żurek i Martyniak 2012; Przybysz i wsp. 2019) o tyle dwa ostatnie są znacznie słabiej rozpoznane pod tym kątem.

Stokłosa bezostna jest gatunkiem pospolitym na stanowiskach suchych, na przydrożach, nasypach, nasłonecznionych skarpach, o podłożu zasobnym w składniki mineralne oraz o odczynie obojętnym lub lekko zasadowym. Gatunek ten może być stosowany do obsiewu łąk i pastwisk na podłożu średnio żyznym, piaszczystym i mogącym okresowo przesychać. Z kolei stokłosa obiedkowata jest gatunkiem mniej popularnym, czasem stosowanym na cele pastewne. Gatunek ten odznacza się dobrą zimotrwałością oraz względnie wysoką odpornością na okresowe susze. Ma niewielkie wymagania glebowe. Gatunek ten może być zatem przydatny do produkcji biomasy na cele energetyczne. W dostępnej literaturze brak jest informacji o potencjale biogazowym tych gatunków.

Celem pracy było określenie wydajności biogazu i plonu metanu oraz dynamiki procesu fermentacji kiszonek $\mathrm{z}$ dwóch wybranych gatunków traw wieloletnich $\mathrm{z}$ rodzaju stokłosa $\mathrm{w}$ ramach poszukiwania alternatywnych substratów dla biogazowni rolniczych.

\section{Material i Metody}

Do badań wybrano dwa gatunki $\mathrm{z}$ rodzaju stokłosa: stokłosa obiedkowata (Bromus catharticus Vahl.), ród nr 19 oraz stokłosa bezostna (Bromus inermis Leyss), ród 1-Lin. Dla porównania zastosowano odmianę pastewna, tetraploidalna 'Flinston' życicy trwałej (Lolium perenne L.).

Doświadczenie polowe z wymienionymi wyżej odmianami traw założono w układzie losowanych bloków w roku 2011 w DANKO Hodowla Roślin sp. z o.o., Zakład Hodowli Roślin Oddział w Szelejewie (woj. wielkopolskie) na średniozwięzłej glebie klasy IV. Gleba ta, określona jako glina piaszczysta, zawierała średnio $68,5 \%$ piasku, $28,5 \%$ pyłu oraz $3 \%$ iłu. Zawartość substancji organicznej wynosiła 1,1\%, odczyn $(\mathrm{pH})-7,2$. Zawartości makroelementów, wyrażone $\mathrm{w}$ mg/l gleby kształtowały się następująco: $\mathrm{N}$ ogólny - 25,8; $\mathrm{P}-64,7$; K - 95,3; $\mathrm{Ca}-712,2$ oraz $\mathrm{Mg}-127,8$.

Warunki pogodowe w latach realizacji doświadczenia były stosunkowo sprzyjające, zwłaszcza opady w miesiącach (czerwiec, lipiec i sierpień) były wysokie (tab. 1).

Wykonano niezbędne prace techniczne i pielęgnacyjne, m.in. przygotowanie stanowiska, uprawę gleby oraz wysiew nawozów mineralnych przedsiewnie w dawce $150 \mathrm{~kg} / \mathrm{ha}$ (Polifoska (6:20:30) oraz wiosną i po każdym pokosie saletrę amonową $34 \% \mathrm{~N}$ w dawce $30 \mathrm{~kg}$ czystego składnika na ha.

Plony biomasy oceniano, kosząc poszczególne odmiany w fazie pełni kłoszenia (pierwszy pokos) oraz po $7-8$ tygodniach odrostu (drugi pokos) oraz za każdy razem zbierając biomasę z powierzchni ok. 10 m² $^{2}$ w $3-4$ punktach na powtórzenie. Koszenia wykonano kosiarką listwową o szerokości roboczej $90 \mathrm{~cm}$ na wysokość ok. $10 \mathrm{~cm}$. Plony oceniano w latach 2012 i 2013.

Badania laboratoryjne wykonano w Laboratorium Badawczym Technologii i Biosystemów Rolniczych Instytutu Technologiczno-Przyrodniczego w Falentach oddział w Poznaniu, które posiadało akredytację polskiego Centrum Akredytacji (PCA) nr AB 116 w zakresie badań zawartości suchej masy, suchej masy organicznej i uzysku biogazu metoda eudiometryczną.

Kiszonki otrzymano z pobranych losowo, świeżo skoszonych części nadziemnych całych roślin w fazie kłoszenia. Kiszonki sporządzono metodą zaszczepiania preparatem Labacsil ${ }^{\circledR}$ firmy Sano. Sieczki o długości odcinków 2-3 cm, zamgławiano mieszaniną Labacsil ${ }^{\circledR}$ Acid i Labacsil ${ }^{\circledR}$ Bakterie zgodnie $\mathrm{z}$ instrukcją producenta $\mathrm{w}$ proporcji dla kiszonki z traw tj.100 1 wody: $10 \mathrm{~kg}$ granulatu Acid: $100 \mathrm{~g}$ liofilizatu Bakterii: $100 \mathrm{t}$ sieczki trawy. Sieczkę $\mathrm{z}$ biomasy umieszczano w odpowietrzanych rękawach foliowych o pojemności 51 i zagęszczano poprzez ubijanie. Proces zakiszania trwał 6 tygodni w temperaturze inkubacji $32^{\circ} \mathrm{C}$, co symulowało warunki panujące we wnętrzu pryzmy. 
Wartości średnich temperatur powietrza oraz miesięczne sumy opadów panujące w okresie realizacji doświadczenia na tle wartości $\mathrm{z}$ wielolecia.

Mean values of monthly air temperature and sum of monthly rainfalls during the vegetation season against the background of normal values.

\begin{tabular}{|c|c|c|c|}
\hline \multirow[b]{2}{*}{ Miesiąc / month } & \multirow[b]{2}{*}{ Rok / Year } & \multicolumn{2}{|c|}{ Parametr: } \\
\hline & & $\begin{array}{c}\text { temperatura / temperature } \\
{\left[{ }^{\circ} \mathrm{C}\right]}\end{array}$ & opad / rainfall $[\mathrm{mm}]$ \\
\hline \multirow{3}{*}{ Marzec / March } & 2011 & 6,0 & 47,2 \\
\hline & 2012 & 5,2 & 38,1 \\
\hline & $1981-2000$ & 3,6 & 37,8 \\
\hline \multirow{3}{*}{ Kwiecień / April } & 2011 & 9,1 & 44,0 \\
\hline & 2012 & 9,6 & 22,0 \\
\hline & $1981-2000$ & 8,8 & 31,3 \\
\hline \multirow{3}{*}{ Maj / May } & 2011 & 13,4 & 13,6 \\
\hline & 2012 & 15,7 & 23,4 \\
\hline & $1981-2000$ & 14,0 & 49,5 \\
\hline \multirow{3}{*}{ Czerwiec / June } & 2011 & 16,6 & 50,2 \\
\hline & 2012 & 16,7 & 79,8 \\
\hline & $1981-2000$ & 16,6 & 56,8 \\
\hline \multirow{3}{*}{ Lipiec/July } & 2011 & 20,1 & 59,4 \\
\hline & 2012 & 19,8 & 85,6 \\
\hline & $1981-2000$ & 18,9 & 75,7 \\
\hline \multirow{3}{*}{ Sierpień / August } & 2011 & 22,8 & 68,8 \\
\hline & 2012 & 19,2 & 73,6 \\
\hline & $1981-2000$ & 18,3 & 60,8 \\
\hline \multirow{3}{*}{ Wrzesień / September } & 2011 & 15,2 & 29,8 \\
\hline & 2012 & 15,9 & 32,8 \\
\hline & $1981-2000$ & 13,7 & 41,7 \\
\hline \multirow{3}{*}{$\begin{array}{c}\text { Średnia - suma za okres } \\
\text { wegetacyjny }\end{array}$} & 2011 & 14,7 & 313,0 \\
\hline & 2012 & 14,6 & 355,3 \\
\hline & $1981-2000$ & 13,4 & 353,6 \\
\hline
\end{tabular}

Analizy chemiczne przeprowadzone zostały w 4 powtórzeniach wg: PN-EN 12880, PN-EN 12879, PN-EN 12176:2001. Określenie wydajności biogazowej oraz charakterystykę dynamiki biogazowania próbek substratów przeprowadzono w oparciu o walidowaną i akredytowaną procedurę badawczą: PB-01/LBMPZ-2008/FM metodą DIN 38 414-S8:1985. Badania wykonano w termostatowanym zestawie eudiometrycznym o pojemności butli fermentacyjnej $1000 \mathrm{ml}$, w eudiometrach o pojemności $600 \mathrm{ml}$ biogazu. Fermentację statyczną prowadzono w temperaturze $37 \pm 0,1^{\circ} \mathrm{C}$, stosując standaryzowany, wygłodzony inoculat bakterii fermentacji metanowej $\mathrm{z}$ hodowli ciagłej $\mathrm{w}$ anaerostacie laboratoryjnym $\mathrm{w}$ ilości $360 \pm 0,5 \mathrm{~g}$, oraz próbki nierozdrabnianych kiszonek traw o masie $40 \pm 0,5 \mathrm{~g}$. Dla każdej kiszonki wykonano badanie w 3 powtórzeniach. Do obliczenia potencjału produkcji biogazu z badanych próbek (biogazodochodowość netto) zastosowano próbę kontrolną inokulatu o masie 400 g. Normalizację codziennych odczytów objętości gazu wykonano dla $0^{\circ} \mathrm{C}$ i $1013 \mathrm{hPa}$. Badanie zawartości metanu i stężenia zanieczyszczeń przeprowadzono wprost $\mathrm{z}$ eudiometrów analizatorem biogazuGA2000firmyGeotechnicalInstrumentsLtd.

O istotności różnic pomiędzy średnimi wartościami cech wnioskowano $z$ prawdopodobieństwem 95\% w oparciu o analizy statystyczne zrealizowane za pomocą pakietu STATISTICA 12.0. Wartości NIR obliczono za pomocą testu Fishera. 
Wyniki oceny plonowania zielonej i suchej masy badanych gatunków traw (średnie z 2 lat pomiarów)

Results of green and dry matter yields estimation for tested grass species (means from two years)

\begin{tabular}{c|c|c|c|c}
\hline \multirow{2}{*}{$\begin{array}{c}\text { Gatunek } \\
\text { Species }\end{array}$} & \multicolumn{3}{|c|}{$\begin{array}{c}\text { Plony zielonej masy [Mg.ha-1] } \\
\text { Green forage yields [Mg ha-1] } \\
\text { pokosy / cuts }\end{array}$} & $\begin{array}{c}\text { Łaczny plon suchej masy } \\
\text { Total dry matter yield } \\
\text { [Mg·ha-1] }\end{array}$ \\
\cline { 2 - 4 } & 1 & 2 & $1+2$ & $6,07 \pm 0,9$ \\
Lolium perenne & 22,3 & 12,0 & 34,3 & $14,2 \pm 2,1$ \\
Bromus catharticus & 33,9 & 31,2 & 65,1 & $8,4 \pm 1,4$ \\
Bromus inermis & 23,7 & 17,9 & 41,6 & 4,2 \\
\hline NIR/LSD $(\mathrm{P}<95 \%)$ & 5,4 & 5,1 & 10,2 & \\
\hline
\end{tabular}

\section{Wyniki i Dyskusja \\ Plony biomasy}

Gatunkiem plonującym najwyżej, spośród badanych w niniejszej pracy, była stokłosa obiedkowata, której średnie plony z 2 lat obserwacji wynosiły ponad 14 ton suchej masy $z$ ha (tab. 2). Bardzo istotny w kształtowaniu plonów tego gatunku był drugi pokos, stanowiący ok. 48\% sumy pokosów. Jest to jedna $\mathrm{z}$ cech charakterystycznych tego gatunku (Falkowski, 1982).

W przypadku stokłosy bezostnej drugi pokos stanowił $43 \%$ całego plonu a dla życicy - 35\%, w przypadku której otrzymano najniższe plony biomasy. Uzyskane w niniejszym doświadczeniu plony mieszczą się w przedziałach wartości uzyskiwanych np. w doświadczeniach porejestrowych COBORU, przez gatunki traw wieloletnich zbliżone pokrojem i potencjałem $\mathrm{w}$ produkcji biomasy do badanych w niniejszym doświadczeniu. Dla przykładu średni plon suchej masy 13 odmian kupkówki pospolitej z doświadczeń w roku 2012 wynosił 13,5 $\mathrm{Mg} \mathrm{ha}{ }^{-1}$, natomiast dla 6 odmian kostrzewy trzcinowej było to $12,9 \mathrm{Mg} \mathrm{ha}^{-1}$. Średnie plony 32 odmian życicy trwałej z lat $2010-$ 2012 wyniosły natomiast $7,9 \mathrm{Mg} \cdot \mathrm{ha}^{-1}$ (COBORU, 2013). W badaniach Skrabka i wsp. (1979) uzyskano podobne wartości plonu suchej masy odmiany 'Una' stokłosy obiedkowatej - od 14 do $18 \mathrm{Mg}$ ha $^{-1}$, w zależności od poziomu nawożenia. Według tych samych autorów, badana równolegle odmiana 'Brudzyńska' stokłosy bezostnej plonowała ok. $28 \%$ niżej niż stokłosa obiedkowata. Podobną zależność odnotowano w niniejszych badaniach, aczkolwiek skala zróżnicowania była większa.

\section{Analizy potencjalu biogazowego kiszonek}

$\mathrm{Z}$ porównania wyników analizy podstawowej wykonanej na próbkach zielonki i kiszonki (tab. 3) badanych roślin wynika, że najniższą zawartością suchej masy (sm) i suchej masy organicznej (smo) charakteryzowały się zarówno świeża jak i kiszona tetraploidalna życica trwała (4x) var. Flinston. W przypadku zielonki było to $17,7 \pm 0,3 \%$ suchej masy i $83,83 \pm 2,51 \%$ suchej masy organicznej. Z kolei w kiszonce parametry te przyjęły wartości, odpowiednio: $14 \pm 0,3 \%$ oraz 79,52 $\pm 2,39 \%$.

Wyliczony ubytek materii organicznej w czasie kiszenia tej odmiany wyniósł $37-42 \mathrm{~g} \cdot \mathrm{kg}^{-1}$. Jednocześnie wszystkie uzyskane wyniki cechowało najniższe odchylenie standardowe, w porównaniu do pozostałych badanych odmian. Może to wskazywać na względnie największą jednorodność badanego materiału odmiany Flinston. Kiszonka z tego gatunku trawy charakteryzowała się dość zbitą i lekko mazistą konsystencją dając największy ubytek objętości i największą ilości odcieku soku kiszonkowego $\mathrm{w}$ stosunku do porównywanych gatunków.

Zielonka stokłosy obiedkowatej charakteryzowała się najwyższymi wynikami zawartości suchej masy $(21,9 \pm 0,4 \%)$ oraz suchej masy organicznej $(89,54 \pm 2,7 \%)$. W przypadku kiszonki było to, odpowiednio $19,1 \pm 0,4 \%$ oraz $87,38 \pm 2,62 \%$. Stosunkowo wysokie odchylenie standardowe świadczy o relatywnie większej niejednorodności struktury materiału roślinnego. Jakościowo kiszonka była najbardziej sypka, o najmniejszych stratach objętości i odcieku, ubytek masy organicznej wynosił

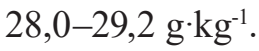

Pośrednie wyniki uzyskano dla stokłosy bezostnej. Z zielonki o zawartości suchej masy $20,2 \pm 0,4 \%$ i suchej masy organicznej $88,9 \pm$ $2,7 \%$, otrzymano kiszonkę o konsystencji lekko zwartej, łatwo rozpadającej się, o średnim ubytku objętości i stracie materii organicznej w zakresie $31,9-32,2 \mathrm{~g} \cdot \mathrm{kg}^{-1}$. Zawartość suchej masy kiszonki to $17,0 \pm 0,3 \%$ a suchej masy organicznej 86,86 $\pm 2,61 \%$. Jest to kiszonka o najwyższym odczynie $\mathrm{pH}$, 
Tabela 3

Table 3

Wyniki analizy podstawowej próbek materiału organicznego zielonek oraz kiszonek badanych traw wieloletnich (średnie \pm błąd standardowy).

Results of basic analysis of green crop and silage made form tested grass species (mean \pm standard errors)

\begin{tabular}{|c|c|c|c|c|c|}
\hline \multirow{2}{*}{$\begin{array}{l}\text { Gatunek/ } \\
\text { Species }\end{array}$} & \multirow{2}{*}{$\mathrm{pH}\left(\mathrm{H}_{2} \mathrm{O}\right)$} & \multicolumn{4}{|c|}{$\mathrm{w} \% /$ in $\%$} \\
\hline & & $\begin{array}{l}\text { sucha masa } \\
\text { dry matter }\end{array}$ & $\begin{array}{l}\text { wilgotność } \\
\text { moisture }\end{array}$ & $\begin{array}{l}\text { sucha masa org. } \\
\text { org. dry matter }\end{array}$ & $\begin{array}{l}\text { popiół } \\
\text { ash }\end{array}$ \\
\hline \multicolumn{6}{|l|}{ Zielonka / Green forage } \\
\hline Lolium perenne & $6,16 \pm 0,02$ & $17,7 \pm 0,3$ & $82,3 \pm 1,6$ & $83,8 \pm 2,5$ & $16,17 \pm 0,5$ \\
\hline Bromus carinathus & $6,52 \pm 0,02$ & $21,9 \pm 0,4$ & $78,0 \pm 1,6$ & $89,5 \pm 2,7$ & $10,5 \pm 0,3$ \\
\hline Bromus inermis & $6,48 \pm 0,02$ & $20,2 \pm 0,4$ & $79,7 \pm 1,6$ & $88,9 \pm 2,7$ & $11,1 \pm 0,3$ \\
\hline \multicolumn{6}{|l|}{ Kiszonka / Silage } \\
\hline Lolium perenne & $4,90 \pm 0,02$ & $14,0 \pm 0,3$ & $86,0 \pm 1,7$ & $79,5 \pm 2,4$ & $20,5 \pm 0,6$ \\
\hline Bromus carinathus & $4,98 \pm 0,02$ & $19,1 \pm 0,4$ & $80,9 \pm 1,6$ & $87,4 \pm 2,6$ & $12,6 \pm 0,4$ \\
\hline Bromus inermis & $6,29 \pm 0,02$ & $17,0 \pm 0,3$ & $83,0 \pm 1,7$ & $86,9 \pm 2,6$ & $13,3 \pm 0,4$ \\
\hline NIR/LSD (P<95\%) & 0,38 & 2,5 & 4,50 & 5,2 & 6,1 \\
\hline
\end{tabular}

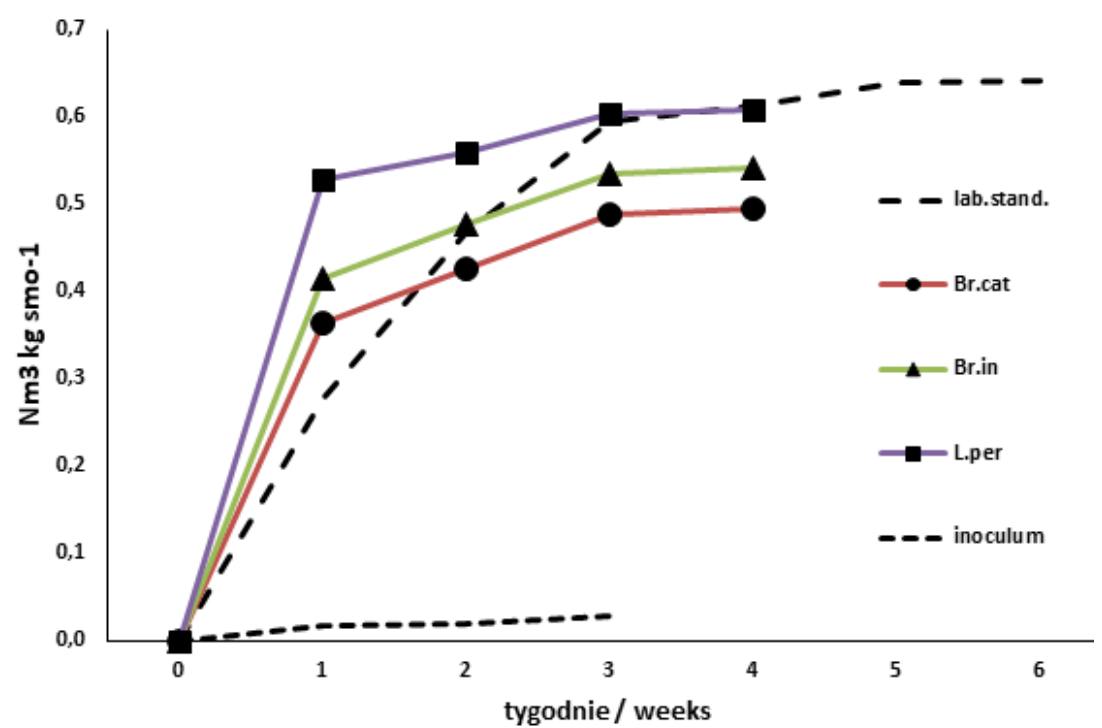

Legenda: lab.stand. - standard laboratoryjny, Br.cat. - Bromus catharticus, Br.in - Bromus inermis, L.per-Lolium perenne.

Ryc. 1. Przebieg fermentacji biogazowej badanych kiszonek $\mathrm{z}$ traw wieloletnich $\mathrm{w}$ porównaniu ze standardem laboratoryjnym - kiszonka z kukurydzy o wydajności $0,642 \mathrm{Nm}^{3} \mathrm{~kg} \mathrm{smo}^{-1}$.

Fig. 1. The course of methane fermentation of sileges made from tested grass species as compared to laboratory standard - maize silage $\left(0.642 \mathrm{Nm}^{3} \mathrm{~kg} \cdot \mathrm{dom}^{-1}\right)$.

który po 6 tygodniach kiszenia wynosił 6,29 i był niewiele bardziej kwasowy niż zielonka, której $\mathrm{pH}$ wynosiło 6,48 .

Wyniki badań dotyczące uzysku biogazu wskazują na wysoki potencjał biogazotwórczy próbek kiszonki z badanych traw oraz zawartość metanu na średnim poziomie. Fermentacja trwała 4 tygodnie i charakteryzowała się bardzo stabilnym przebiegiem (ryc. 1).

W przeliczeniu na zawartość suchej masy organicznej najwyższy potencjał $\mathrm{w}$ zakresie produkcji biogazu wynoszący $0,6119 \pm 0,0324 \mathrm{Nm}^{3} \mathrm{~kg} \cdot \mathrm{smo}^{-1}$, przy średnim stężeniu metanu $54,8 \%$ prezentowała kiszonka z życicy trwałej. Biomasa traw z rodzaju stokłosa wykazała niższy potencjał do produkcji biogazu, w zakresie od 0,4852 $\pm 0,0257$ $\mathrm{Nm}^{3} \mathrm{~kg} \cdot \mathrm{smo}^{-1}$ (stokłosa obiedkowata) do 0,5183 $\pm 0,0275 \mathrm{Nm}^{3} \mathrm{~kg} \cdot \mathrm{smo}^{-1}$ (stokłosa bezostna), $\mathrm{z}$ kolei stężenie metanu było niższe i nie przekraczało $50,5 \%$.

Jak obrazuje wykres przebiegu fermentacji (rys. 1), dynamika procesu była przyspieszona 
Tabela 4

Table 4

Średnie stężenia metanu i zanieczyszczeń biogazu w przebiegu fermentacji biogazowej próbek materiału organicznego badanych gatunków traw wieloletnich

Mean methane concentration and biogas impurities after fermentation of organic material samples of tested perennial grasses

\begin{tabular}{c|c|c|c|c|c}
\hline $\begin{array}{c}\text { Parametry jakościowe biogazu / } \\
\text { Biogas quality parameters }\end{array}$ & Lolium perenne & Bromus catharticus & Bromus inermis & K0 - inoculat & $\begin{array}{c}\text { NIR / LSD } \\
(\mathrm{P}<95 \%)\end{array}$ \\
\hline $\begin{array}{c}\text { Uzysk biogazu }\left[\mathrm{Nm}^{3} / \mathrm{kg} \mathrm{smo}\right] / \\
\text { Biogas yield }\left[\mathrm{Nm}^{3} / \mathrm{kg} \mathrm{odm}\right]\end{array}$ & $0,612 \pm 0,03$ & $0,485 \pm 0,026$ & $0,518 \pm 0,028$ & $0,029 \pm 0,001$ & 68,2 \\
$\mathrm{CH}_{4}[\%]$ & 54,8 & 50,23 & 50,42 & 49,2 & 1,3 \\
$\mathrm{CO}_{2}[\%]$ & 36,1 & 38,33 & 41,18 & 43,82 & 2,5 \\
$\mathrm{O}_{2}[\%]$ & 0,43 & 0,13 & 2,38 & 2,38 & 1,1 \\
$\left.\mathrm{H}_{2} \mathrm{~S}[\mathrm{mg} \mathrm{kg}-1]\right]$ & 272 & 280 & 298 & 36 & 15,1 \\
$\mathrm{~N}_{2} \mathrm{O}[\mathrm{mg} / \mathrm{m} 3]$ & 8,4 & 6,25 & 7,6 & 0,45 & 1,25 \\
$\mathrm{NH}_{3}[\mathrm{mg} / \mathrm{m} 3]$ & 1,2 & 0,51 & 1,04 & $0,01 *$ & 0,91 \\
\hline
\end{tabular}

i wyprzedzająca w stosunku do standardu laboratoryjnego (kiszonka z kukurydzy), co było szczególnie wyraźne w przypadku życicy trwałej. Proces spowolniony ale wyprzedzający $\mathrm{z}$ równomiernym zgazowywaniem zaobserwowano dla kiszonki ze stokłosy bezostnej.

Badane próbki uległy fermentacji w czasie krótszym niż standard laboratoryjny. Po 3 tygodniach fermentacji uzyskano z nich już ponad 98\% całej ilości biogazu, podczas gdy dla standardu laboratoryjnego było to $92,5 \%$. Fakt ten może mieć znaczenie w kontekście ekonomiki wykorzystania fermentatora. Praktycznie, po upływie 3 tygodni od rozpoczęcia fermentacji kiszonki z badanych gatunków traw wieloletnich można dokonać kolejnego napełnienia zbiornika i zainicjować kolejny proces produkcji biogazu. Kiszonka z kukurydzy potrzebuje natomiast jeszcze ok. 2 tygodni aby zakończyć wygazowywanie. Zastosowanie kiszonki z traw takich jak te, które opisywane są w niniejszej pracy, zwiększa przepustowość komory fermentacyjnej, umożliwiając uzyskanie większej ilości biogazu $\mathrm{w}$ jednostce czasu.

W przypadku nowo budowanych biogazowni, skrócenie wygazowywania (tzw. retencji) biomasy, pozwala na wybudowanie komór fermentacyjnych o mniejszej pojemności całkowitej, co stanowi ewidentną oszczędność dla inwestora. Dlatego też przed podjęciem decyzji o wielkości mocy planowanej biogazowni należy bezwzględnie zasięgnąć informacji w kompetentnej placówce naukowo badawczej co do składu biomasy optymalnej dla danego rodzaju gleby w lokalizacjach, z których mogłaby być kontraktowana biomasa, $\mathrm{z}$ równoczesnym uwzględnieniem optymalnych parametrów wygazowania (Łukaszek i wsp. 2011).
Uwzględniając uzyskane plony biomasy, ilości biogazu oraz oznaczoną w nim zawartość metanu można określić potencjalny plon metanu $\mathrm{z}$ jednostki powierzchni uprawy (rys. 2). Najwyższą wartość tej cechy stwierdzono dla stokłosy obiedkowatej - było to średnio $3104,1 \mathrm{Nm}^{3} \cdot \mathrm{ha}^{-1}$ metanu. Dla pozostałych gatunków uzyskano mniejsze wartości - od 1951,3 $\mathrm{Nm}^{3} \cdot \mathrm{ha}^{-1}$ dla stokłosy bezostnej po 1706 $\mathrm{Nm}^{3} \cdot \mathrm{ha}^{-1}$ dla życicy trwałej (rys. 2).

Uzyskane wyniki wskazują na decydującą rolę plonu biomasy z jednostki powierzchni w kształtowaniu efektywności pozyskiwania metanu. Podobne wyniki uzyskali np. Ust’ak i wsp. (2013) dla życicy trwałej $\left(1974,0 \mathrm{Nm}^{3} \cdot \mathrm{ha}^{-1}\right)$, w porównaniu do np. kupkówki (2555 $\left.\mathrm{Nm}^{3} \cdot \mathrm{ha}^{-1}\right)$ czy kostrzewy trzcinowej $\left(2648 \mathrm{Nm}^{3} \cdot \mathrm{ha}^{-1}\right)$. Wydajności biogazu z biomasy roślin łąkowych i traw zazwyczaj wahają się w granicach od ok. 0,460 do ponad 0,600 $\mathrm{Nm}^{3} \mathrm{~kg} \cdot \mathrm{smo}^{-1}$ (Matyka i Księżak 2012; Mast i wsp. 2014).

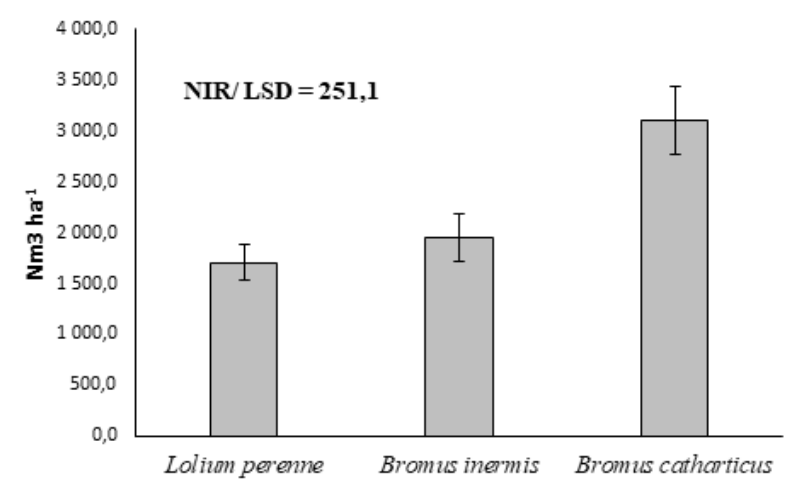

Ryc. 2. Plon metanu z jednostki powierzchni uprawy badanych gatunków traw.

Fig. 2. Methane hectare yield for tested grass species. 
Roślinami o relatywnie największych wartościach tej cechy, oprócz kukurydzy, są rośliny cyklu C4 fotosyntezy, takie jak sorgo czy gatunki z rodzaju miskantus (El Bassam, 2010; Purwin i wsp. 2014). Co ciekawe, również stokłosa obiedkowata uważana jest za gatunek wykazujący pewne cechy metaboliczne fotosyntezy typu C4 (Falkowski, 1982). W wypadku tego gatunku przekłada się to np. na wyrównane plonowanie w sezonie. Oprócz tego gatunek ten charakteryzuje się dużą ilością cukrów redukujących w okresie letnim oraz dużą zawartością celulozy, hemicelulozy i lignin (Falkowski, 1982). W niniejszym opracowaniu dla gatunku tego stwierdzono relatywnie najniższą wartość produkcji biogazu z jednostki suchej masy organicznej a uzyskany wynik, związany z największym plonem metanu $\mathrm{z}$ jednostki powierzchni uprawy jest konsekwencją najwyższego plonu biomasy.

\section{Wnioski}

1. Stwierdzono różnice w wydajności biogazowej badanych odmian traw z rodzaju stokłosa, z których w stosunku do standardu laboratoryjnego (kiszonka z kukurydzy, 0,642 $\mathrm{Nm}^{3}$ $\mathrm{kg} \cdot \mathrm{smo}^{-1}$ ) uzyskano od ok. $20 \%$ do $29 \%$ mniej biogazu (odpowiednio, 0,518 $\mathrm{Nm}^{3} \mathrm{~kg} \cdot \mathrm{smo}^{-1}-$ stokłosa bezostna, $0,458 \quad \mathrm{Nm}^{3} \quad \mathrm{~kg} \cdot \mathrm{smo}^{-1}$ - stokłosa odbiedkowata).

2. Najwyższy plon metanu $\mathrm{z}$ jednostki powierzchni uprawy $\left(3104,1 \mathrm{Nm}^{3} \cdot \mathrm{ha}^{-1} \mathrm{CH}_{4}\right)$ stwierdzono dla stokłosy obiedkowatej. Dla pozostałych badanych gatunków traw wartości tej cechy były znacznie niższe.

3. Czynnikiem determinującym ilość uzyskanego metanu z jednostki powierzchni uprawy badanych gatunków traw z rodzaju stokłosa był plon biomasy.

4. Kiszonka uzyskana ze stokłosy bezostnej charakteryzowała się znacznie przyspieszoną, w porównaniu do kukurydzy, dynamiką wygazowania. Cecha ta jest bardzo istotna w kontekście skrócenia procesu fermentacji.

5. Trawy wieloletnie, w tym również badane gatunki $\mathrm{z}$ rodzaju stokłosa, stanowią cenny surowiec dla biogazowni pozyskany z gleb o słabej wartości rolniczej.

\section{Literatura}

COBORU. (2013). Wyniki porejestrowych doświadczeń odmianowych. Trawy pastewne 2012 (kostrzewa czerwona, kostrzewa łąkowa, kostrzewa trzcinowa, kupkówka pospolita, życica trwała). Nr. 100, Wyd. Centralny Ośrodek Badania Odmian Roślin Uprawnych, 65/2013, n.350 str. 1-80.
Dickeduisberg M., Laser, H., Tonn, B., Isselstein, J. (2017). Tall wheatgrass (Agropyron elongatum) for biogas production: crop management more important for biomass and methane yield than grass provenance. Industrial Crops and Products, 97: 653-663.

El Bassam, N. (2010). Handbook of bioenergy crops. Earthscan, 1-516.

Falkowski, M. (1982). Trawy Polskie. PWRiL, Warszawa, s. 565.

Kulig, R., Skonecki, S., Michałek, W., Martyniak, D., Piekarski, W., Różyło, R. (2015). The compaction process of Andropogon gerardii in terms of the production of ecological solid fuel. Polish Journal of Environmental Studies, 24 (6): 2473-2477.

Lalak, J., Kasprzycka, A., Martyniak, D., Tys, J. (2017). Effect of biological treatment of Agropyron elongatum 'BAMAR' on biogas production by anaerobic digestion. Bioresource Technology, 200 (2016):194-200.

Łukaszek, O., Łukaszek, W., Bartkiewicz, K. (2011). Polska technologia produkcji energii elektrycznej - aspekty ekonomiczne, techniczne i surowcowe. Czysta Energia, nr 7- 8/2011: 40-42.

Martyniak D., Martyniak J. (2011). Perz wydłużony - źródłem taniej fitoenergii (bioenergii). Czysta Energia nr 7 8/2011: 20-21.

Martyniak D., Żurek G., Prokopiuk K. (2017). Biomass yield and quality of wild populations of tall wheatgrass [Elymus elongatus (Host.) Runemark]. Biomass \& Bioenergy, 10: 21-29.

Mast, B., Lemmer, A., Oechsner, H., Reinhardt-Hanisch, A., Claupein, W.,Graeff-Hönninger, S., (2014). Methane yield potential of novel perennial biogascrops influenced by harvest date. Ind. Crops Prod. 58, 194-203.

Matyka, M., Księżak, J. (2012). Plonowanie wybranych gatunków roślin, wykorzystywanych do produkcji biogazu. Probl. Inż. Roln. (I-III): 1 (75) s. 69-75.

Purwin, C., Pysera, B., Fijałkowska, M., Tywonczuk, J. (2014). Efektywne metody konserwacji biomasy z celowych upraw energetycznych. W: Gołaszewski J. (red.) Modelowe kompleksy agroenergetyczne: technologie pozyskania i kondycjonowania biomasy rolniczej i wodnej dla biogazowni i zgazowarki. Wydawnictwo UW-M, Olsztyn, 396-415.

Skrabka, H., Stachurska, A., Szuwalska, Z. (1979). Dynamika przyrostu masy i produktywność stokłosy bezostnej i stokłosy uniolowatej przy zróżnicowanym nawożeniu azotem w doświadczeniu polowym. Cz. I. Wskaźniki produktywności i plony. Acta Agrobotanica, vol. XXXII, (1): 53-68.

StatSoft Inc. (2014). STATISTICA (data analysis software system), version 12. www.statsoft.com.

Przybysz, K., Małachowska, W., Martyniak, D., Boruszewski, P, Kalinowska, H., Przybysz, P. (2019). Production of Sugar Feedstocks for Fermentation Processes from Selected Fast Growing Grasses. Energies, 12, 3129. 
Ust'ak, S., Kohoutek, A., Muñoz, J., Odstraćilova, V., Komárek, P., Nerušil, P., Němcová, P. (2013). Potential production of biogas of selected grassland species from renovated grasslands. Grassland Science in Europe, vol. 18: $572-574$.
Żurek, G., Martyniak, D. (2012). Energia odnawialna z biomasy traw wieloletnich - perspektywy i bariery. W: Praca zbiorowa pod red. B. Mickiewicza, Najnowsze osiągnięcia z zakresu OZE wraz z przedstawieniem barier we wdrażaniu wyników badań do praktyki gospodarczej oraz sugestiami ich rozwiązań. Wyd. Feniks, Koszalin: $145-159$. 